\title{
The Beginnings of an Outline for Jews to Consider
}

\author{
Undated
}

Beerman here offers up a series of guiding principles that define his vision of Judaism as it operates in his life. Medieval Jewish thinkers such as Maimonides (1135-1204) and Yosef Albo (ca.1380-1444) formulated their own ikarim, or foundational principles, as a means of delineating the unique properties of Judaism and of distinguishing it from other traditions. Rabbi Beerman's list serves less as a magnet to fellow Jews, as in the case of his medieval precursors, and more as a credo of faith about the ideals and practices that animated him as a Jew. He never published the list, but kept it on the desk in his office as a reminder of the key values dear to him.

1. Judaism teaches me that each human being is created in the image of God; therefore each is entitled to respect, to dignity. I am to love my neighborhow? - as myself. We are all of us creatures of dignity, not meant to abuse, use, manipulate one another-To be created in the image of God-that is a cardinal principle-Ben Azzai taught.

2. Judaism provides me with a framework of ideas about man, about God, about the good life, a library of human experience, of questions and answers about life and its meaning. It provides the framework; I must myself build, fill in the details, finish the work ... and the work never ends.

3. Judaism gives me time for prayer, for serenity, for wisdom - those prayers and those silences have challenged me, irritated me, frightened me-as I respond to them.

4. Judaism gives me customs, traditions, they enrich my life, help me to hallow my days. I cannot eat without reciting a blessing. 
5. Judaism gives me a reverence for learning — the search for truth—"thou shalt teach them diligently," a respect for the thoughtful man-perhaps that is what it means to be made in the image of God-to be endowed with reason, the ability to think - that is the way Maimonides saw it.

6. Judaism helps me to understand that I am not alone; I am a part of a people, an eternal people. My ancestors were slaves in Egypt, they stood at Sinai to receive those commandments-I was at Sinai too, I went forth out of Egypt or I am yearning to go forth. This IS Egypt. This place. This America. The process of liberation is an eternal one.

7. Judaism teaches me about the way, the way a Jew can live in order to be a man. It has taught me to abhor war, violence, to seek the way of peace. It has taught me not to be ashamed of gentleness, of compassion.

8. Judaism teaches me to be sensitive to injustice. To have been a slave, to have been an alien in every generation - is to know the heart of the stranger, to know what brings pain to another, and never to be at ease so long as a single person is denied his humanity.

9. I pass this world but once-whatever good I can do, do it now. I want to leave this place better for having lived in it. And this life is all and enough for me. Do it now!

10. Hillel's principle-what is hateful unto thee do not do unto thy fellowman. The negative and Jewish statement of the principle is crucial, as Ahad Haam once perceived. There is a principle of justice for all men to keep. I am not good to another so that he will in turn be good to me.

11. Being a Jew is being part of a Jewish people, being members of a special family. I have brothers and sisters in Israel for whom I care, from whom perhaps I can learn new ways of being a Jew.

\section{COMMENTARY BY AZIZA HASAN}

Rabbi Beerman lived a commitment to be good to others. To be gentle, caring, loving, and compassionate. I remember being dumbfounded the first time he delivered criticism to me directly. His voice was soft and yet painfully powerful when he told me that "organizations like NewGround come and go with the wind." The words struck me, but his delivery helped me hear his message. His words and example serve as a guide and a source of inspiration-living each of the articles of faith above. Articles that compel me as a Muslim woman to tap back into teachings in Islam. Most of all, what speaks to me of Rabbi Beerman's writing and example was his commitment to live in kindness and compassion-bringing to life Islamic text that calls on people to do what is better so that the enemy may become a dear friend (Quran 41:34). Firmly grounded in religious text, his words remind that I should not be ashamed of being a gentle and compassionate peacemaker. 
Something I have struggled with is to be taken seriously in a world dominated by men, and yet my commitment to communicating in that way has helped others see my work and join my efforts to build bridges and strengthen my organization. These eleven points connect to my own foundation in Islam and my ability to live faithfully and care for the community around me. 